\title{
Integrase Strand Transfer Inhibitors in HIV Therapy
}

Thibault Mesplède $\cdot$ Mark A. Wainberg

To view enhanced content go to www.infectiousdiseases-open.com

Received: October 2, 2013 / Published online: November 19, 2013

(C) The Author(s) 2013. This article is published with open access at Springerlink.com

\section{ABSTRACT}

HIV drug resistance has been one of the major obstacles to HIV eradication and has contributed to the need for the constant development of new antiretroviral drugs over the past 25 years. With the recent approval of dolutegravir for human therapy by the U.S.

Electronic supplementary material The online version of this article (doi:10.1007/s40121-013-0020-8) contains supplementary material, which is available to authorized users.

T. Mesplède · M. A. Wainberg (ه)

McGill University AIDS Centre, Lady Davis Institute for Medical Research, Jewish General Hospital, Montréal, QC, Canada

e-mail: mark.wainberg@mcgill.ca

\section{A. Wainberg}

Division of Experimental Medicine, Faculty

of Medicine, McGill University, Montréal,

QC, Canada

\section{A. Wainberg}

Department of Microbiology and Immunology, Faculty of Medicine, McGill University, Montréal, QC, Canada

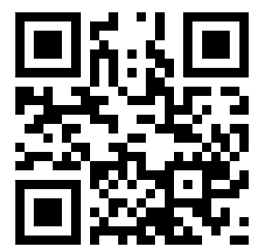

Enhanced content for this article is

available on the journal web site:

www.infectiousdiseases-open.com
Food and Drug Administration, health practitioners may soon have access to three integrase strand transfer inhibitors to treat individuals living with HIV. Here, we review the use of raltegravir, elvitegravir, and dolutegravir for use in first- and second-line HIV treatment regimens and the issue of HIV resistance against integrase inhibitors.

Keywords: Dolutegravir; Elvitegravir; HIV; Infectious disease; Integrase inhibitors; Raltegravir; Resistance; Sequencing

\section{INTRODUCTION}

Current highly active antiretroviral therapy (HAART) against HIV infection has, until recently, typically consisted of two reverse transcriptase inhibitors and a ritonavir-boosted protease inhibitor or a non-nucleoside reverse transcriptase inhibitor (NNRTI) for treatmentnaïve adults [1]. HIV drug resistance threatens the long-term efficacy of HAART in both developed and developing country settings (reviewed in [2-4]) and this has led to the development of a new class of drugs termed integrase inhibitors. As is the case for all 
antiretroviral drugs, HIV has the ability to acquire resistance against integrase inhibitors and this occurs through discrete mutations in the integrase coding sequence (reviewed in [5-8]). These mutations can be analyzed according to several genotyping resistance interpretation algorithms.

The issue of whether various integrase inhibitors may be used sequentially, i.e., in a sequential strategy, is a subject of great potential importance. Indeed, this concept has been studied from the beginnings of the field of antiretroviral therapy to develop strategies that might enable patients to benefit from newer classes of drugs, even if they had previously failed therapy while on older compounds against which resistance had developed [3]. In some cases, newer compounds could be used even within single drug classes to provide patient benefit in the event of resistance. A good example of this has been the use of ritonavir-boosted darunavir (DRV) that has a high genetic barrier for resistance for use in the place of earlier protease inhibitors such as nelfinavir (NFV) and ritonavir-boosted lopinavir (LPV) that have lower genetic barriers to resistance [9-12]. Due to the fact that ritonavir helps to maintain higher levels of PIs in the blood and tissues of treated individuals, the action of these compounds is prolonged and their genetic barrier for resistance is increased.

It has also long been established that members of different drug families may be used even if resistance has developed against members of other drug classes. As an example, the development of drug resistance to the NNRTI family of compounds can often be confronted through the use of protease inhibitors, since no cross-resistance exists between these two drug classes. More recently, newer NNRTI compounds that have somewhat distinct resistance profiles have also been developed to provide benefits to patients when these compounds are used as a part of a secondline regimen [13].

In this context, the discovery of integrase strand transfer inhibitors (INSTIs) is important as a means of extending therapeutic options for individuals living with HIV. The integrase gene and enzyme of HIV were recognized early to be a potential therapeutic target and were shown to be susceptible to inhibition by oligonucleotides and synthetic peptides as early as 1995 [14, 15]. However, a seminal study only described the first promising small compound targeting integrase in 2000 [16]. This, in turn, has led to the development of all currently approved integrase inhibitors.

In the USA, INSTIs currently available for HIV treatment include raltegravir (RAL), elvitegravir (EVG), and dolutegravir (DTG). Integration is a two-step reaction catalyzed by the HIV integrase protein (reviewed in [17, 18]). The first step consists of the processing of the $3^{\prime}$ end of the newly retrotranscribed double-stranded viral DNA and is followed by the strand transfer reaction that results in the irreversible insertion of the viral genome into the host DNA. RAL, EVG, and DTG specifically inhibit the strand transfer step of integration $[16,19]$. INSTIs have demonstrated long-term safety and efficacy [20-24] for the treatment of individuals living with multiple HIV subtypes [25-27]. Here, we review the use of INSTIs in first- and second-line HIV treatment regimens, as well as the potential to use these drugs sequentially after treatment failure as well as the issue of resistance.

\section{METHODS}

The analysis in this article is based on previously conducted studies, and does not 
involve any new studies of human or animal subjects performed by any of the authors. Clinical studies reviewed in this manuscript were deemed important to the field of HIV integrase inhibitors by the authors. Most of these studies included large cohorts of patients. We also searched PubMed using the terms "raltegravir", "elvitegravir", and "dolutegravir" as well as both the previous and brand names for these drugs.

\section{INTEGRASE INHIBITORS FOR FIRST- AND SECOND-LINE TREATMENT}

INSTIs have been used in clinical trials in antiretroviral treatment-naïve individuals living with HIV (Table 1) [24, 28-47]. Both RAL [24, 28-32] and cobicistat (c)-boosted EVG $[33,34]$ have demonstrated non-inferiority to efavirenz (EFV) when co-administered in combination with tenofovir (TDF)/ emtricitabine (FTC). EVG/c is also non-inferior to $\mathrm{ATV} / \mathrm{r}$ when combined with TDF/FTC [35, 36]. Non-inferiority was also demonstrated for DTG compared to EFV in the SPRING-1 (A Dose Ranging Trial of GSK1349572 and 2 NRTI in HIV-1 Infected, Therapy Naive Subjects) study in which patients were randomized to receive either TDF/FTC or abacavir (ABC)/lamivudine (3TC) $[37,38]$. More recently, the SINGLE (A Trial Comparing GSK1349572 $50 \mathrm{mg}$ Plus Abacavir/Lamivudine Once Daily to Atripla) study compared DTG/abacavir ABC/3TC to EFV/TDF/FTC and showed that the former regimen offered a superior virological response than the latter [39]. Although EVG is coformulated in a single pill with cobicistat (c) plus FTC/TDF, RAL and DTG might also be able to be co-formulated with nucleoside drugs, and all of the INSTIs can probably be co- formulated with protease inhibitors for use in first-line treatment [48-54].

Importantly, INSTIs can be used for secondline treatment against HIV strains that are resistant against other drug classes, including NRTI, NNRTI, and PI [55-62] (Table 1). In particular, RAL was shown to be efficacious for patients who displayed resistance to three classes of drugs other than INSTIs [58]. In addition, RAL combined with a ritonavirboosted PI was non-superior to ritonavirboosted PIs plus two or three NRTIs in patients who had previously failed NNRTI-based treatments [40]. RAL was also non-inferior to $\mathrm{LPV} / \mathrm{r}$ as a second-line drug for patients who had failed regimens consisting of a NNRTI and two NRTIs [41].

Treatment-experienced patients can also benefit from the use of INSTIs for reasons of toxicity, convenience, or absence of drug interactions [41, 63, 64]. Although switching from $\mathrm{LPV} / \mathrm{r} / \mathrm{TDF} / \mathrm{FTC}$ to $\mathrm{RAL} / \mathrm{DRV} / \mathrm{r}$ in individuals with suppressed viral load resulted in sustained viral suppression, it did not improve renal function at week 48 [42]. In contrast, RAL has a positive impact on bone mineral density compared to standard secondline treatments [5]. Whether treatment intensification with INSTIs might benefit individuals with suppressed viral loads is beyond the scope of this review [65-69].

Studies have compared the efficacy of the different INSTIs in suppressing HIV viral load. In the 145 Study, EVG demonstrated noninferiority to RAL at weeks 48 and 96 in highly treatment-experienced patients [43, 44]. DTG was non-inferior to RAL in attainment of viral suppression in treatment-naïve individuals at week 48 [45]. In contrast, DTG performed better than RAL in highly treatment-experienced INSTI-naïve individuals who were enrolled in a 
Table 1 Summary of the major clinical trials reviewed in this publication

\begin{tabular}{|c|c|c|c|c|c|}
\hline Study name & Tested regimen & & Reference regimen & $\begin{array}{l}\text { Antiviral activity of the } \\
\text { tested regimen compared } \\
\text { to the reference regimen }\end{array}$ & References \\
\hline $\begin{array}{l}\text { STARTMRK, } \\
\text { Protocol 004, } \\
\text { QDMRK }\end{array}$ & $\mathrm{RAL}+\mathrm{TDF} / \mathrm{FTC}$ & vs. & $\mathrm{EFV}+\mathrm{TDF} / \mathrm{FTC}$ & Non-inferiority & {$[24,28-32]$} \\
\hline GS-US-236-0102 & $\mathrm{EVG} / \mathrm{c}+\mathrm{TDF} / \mathrm{FTC}$ & vs. & $\mathrm{EFV}+\mathrm{TDF} / \mathrm{FTC}$ & Non-inferiority & {$[33,34]$} \\
\hline GS-236-0103 & $\mathrm{EVG} / \mathrm{c}+\mathrm{TDF} / \mathrm{FTC}$ & vs. & $\mathrm{ATV} / \mathrm{r}+\mathrm{TDF} / \mathrm{FTC}$ & Non-inferiority & {$[35,36]$} \\
\hline SPRING-1 & $\begin{array}{l}\mathrm{DTG}+\mathrm{TDF} / \mathrm{FTC} \text { or } \\
\mathrm{ABC} / 3 \mathrm{TC}\end{array}$ & vs. & $\begin{array}{l}\mathrm{EFV}+\mathrm{TDF} / \mathrm{FTC} \text { or } \\
\mathrm{ABC} / 3 \mathrm{TC}\end{array}$ & Non-inferiority & {$[37,38]$} \\
\hline SINGLE & $\mathrm{DTG}+\mathrm{ABC} / 3 \mathrm{TC}$ & vs. & $\mathrm{EFV}+\mathrm{TDF} / \mathrm{FTC}$ & Superiority & [39] \\
\hline Study 145 & $\mathrm{EVG}+\mathrm{PI} / \mathrm{r}+3 \mathrm{rd}$ drug & vs. & $\begin{array}{l}\mathrm{RAL}+\mathrm{PI} / \mathrm{r}+3 \mathrm{rd} \\
\text { drug }\end{array}$ & Non-inferiority & {$[43,44]$} \\
\hline SPRING-2 & $\begin{array}{l}\mathrm{DTG}+\mathrm{TDF} / \mathrm{FTC} \text { or } \\
\mathrm{ABC} / 3 \mathrm{TC}\end{array}$ & vs. & $\begin{array}{l}\text { RAL + TDF/FTC } \\
\text { or } \mathrm{ABC} / 3 \mathrm{TC}\end{array}$ & Non-inferiority & {$[45]$} \\
\hline SAILING & $\begin{array}{l}\text { DTG }+1 \text { or } 2 \text { active } \\
\text { drugs }\end{array}$ & vs. & $\begin{array}{l}\text { RAL }+1 \text { or } 2 \text { active } \\
\text { drugs }\end{array}$ & Superiority & {$[46]$} \\
\hline EARNEST & RAL + boosted PI & vs. & $\begin{array}{l}\text { Boosted PI }+2 \text { or } 3 \\
\text { NRTIs }\end{array}$ & Non-inferiority & {$[40]$} \\
\hline Second-Line & $\mathrm{RAL}+\mathrm{LPV} / \mathrm{r}$ & vs. & $\begin{array}{l}\mathrm{LPV} / \mathrm{r}+2 \text { or } 3 \\
\text { NRTIs }\end{array}$ & Non-inferiority & {$[41]$} \\
\hline FLAMINGO & $\begin{array}{l}\mathrm{DTG}+\mathrm{TDF} / \mathrm{FTC} \text { or } \\
\mathrm{ABC} / 3 \mathrm{TC}\end{array}$ & vs. & $\begin{array}{c}\mathrm{DRV} / \mathrm{r}+\mathrm{TDF} / \mathrm{FTC} \\
\text { or } \mathrm{ABC} / 3 \mathrm{TC}\end{array}$ & Superiority & {$[47]$} \\
\hline
\end{tabular}

RAL raltegravir, TDF tenofovir disoproxil fumarate, FTC emtricitabine, $E F V$ efavirenz, $E V G / c$ cobicistat-boosted elvitegravir, $A T V / r$ ritonavir-boosted atazanavir, $A B C$ abacavir, $3 T C$ lamivudine, $D T G$ dolutegravir, $P I$ protease inhibitor, $L P V / r$ ritonavir-boosted lopinavir

study termed SAILING (A Study of GSK1349572 Versus Raltegravir (RAL) With Investigator Selected Background Regimen in AntiretroviralExperienced, Integrase Inhibitor-Naive Adults) [46]. Overall INSTI-based regimens have shown low toxicity and an absence of unfavorable drug-drug interactions. The yearly costs of the various INSTI-containing regimens are comparable among the three drugs, i.e., approximately 30,000 USD/year [70].

\section{SEQUENTIAL STRATEGY FOR THE USE OF INTEGRASE INHIBITORS AND THE ISSUE OF RESISTANCE}

The concept of sequential strategy in regard to integrase inhibitors has not been fully explored. Although little information is available on this subject, the following facts are well-known. First, it is unlikely that RAL and EVG will ever 
be able to be used sequentially in therapy, since the resistance profiles of these two compounds overlap to considerable extent $[5,6]$. The only possibility for use of these compounds in sequential fashion might be if a change in therapy is contemplated at a time that resistance has not yet developed against either of these agents. The rationale for such a substitution could include the fact that RAL is a twice-daily drug and that some patients might prefer to be on the once-daily regimen of coformulated EVG/c/TDF/FTC. In contrast, there are some patients who cannot take a pharmacological booster such as cobicistat for reasons of drug interactions and who might need instead to take the twice-daily regimen of RAL, complemented by two members of the nucleoside family of drugs [70].

The use of DTG to rescue patients who have first developed resistance to RAL has also been studied and documented [71]. In almost all cases, it appears as though some measure of patient benefit can be obtained if DTG is used to treat individuals who have developed resistance to either RAL or EVG, after the development of mutations in the integrase gene that follow one of the well-described resistance pathways for these compounds. However, it should also be noted that DTG may not be as effective in this setting as it is in first-line therapy. Indeed, the VIKING (A Pilot Study Assessing the Integrase Inhibitor GSK1349572 in HIV-infected Persons With Virus Resistant to Raltegravir) clinical trials in which DTG was used to rescue patients who first developed resistance against RAL showed that patients will have to receive DTG bid dosing at a total intake that is double the dose of DTG that is commonly used in first-line therapy [71]. The results also suggest that patients who first develop mutations that follow the RAL/EVG $148 / 140$ mutational pathway are less likely to respond to DTG than are INSTI-naïve individuals. This raises the important question of whether DTG can be saved for use as part of a second-line regimen, instead of being used in first-line therapy. Clearly, patients who have failed RAL or EVG and who have few other treatment options might benefit from the use of DTG and should be treated with this drug. However, this does not mean that DTG should be saved for use in later treatment regimens. In support of this, the FLAMINGO (Dolutegravir Compared to Darunavir/ Ritonavir, Each in Combination With Dual Nucleoside Reverse Transcriptase Inhibitors (NRTIs) in ART-naive Subjects) study recently demonstrated the superiority of DTG over $\mathrm{DRV} / \mathrm{r}$ in first-line therapy, when patients also received two nucleos(t)ides [47].

\section{SHOULD DTG BE USED AS A FIRST-LINE DRUG?}

The danger of delaying the use of DTG is that significant numbers of individuals who develop resistance to RAL and/or EVG may, by that time, have lost their ability to respond in fully efficacious fashion to DTG. For example, the results of the VIKING studies raise the issue of durability of responsiveness to a DTG-based regimen in second-line therapy after relevant INSTI mutations for RAL and EVG are already in place.

Further information on this topic is provided by the results of the SAILING study that evaluated the use of RAL vs. DTG in a context in which previously treatment-experienced patients had received therapy with many other types of drugs but not with INSTIs. Moreover, the patients in this trial had developed resistance against many of the compounds that were used 
in prior therapy. Accordingly, almost all of them had compromised background regimens that involved the use of the various antiretroviral compounds that were employed. The results of the SAILING study show clearly that DTG outperformed RAL in terms of percentage of patients who achieved significant drops in viral load [46]. This is important, as it suggests that DTG is a more potent compound than RAL when either of these drugs is used in a salvage setting for patients who have previously failed traditional drug regimens that did not include an INSTI. At the same time, patients in the RAL arm of the trial who developed resistance against the latter compound did so due to development of mutations that are associated with the latter drug. In contrast, patients in the DTG arm of the trial developed resistance in very few cases. Two individuals developed the R263K mutation [72] that had earlier been shown to be of potential significance for DTG on the basis of tissue culture selection studies [73]. Accordingly, it appears that resistance to DTG in the clinic may be very difficult to develop, even in the case of patients who have previously failed other drug regimens and who are currently being treated with DTG, almost in the context of functional monotherapy. This suggests that it may be very difficult to develop resistance against DTG under circumstances in which this compound is used as part of a first-line INSTI regimen. This may be because the mutations that develop against DTG, when the latter is used in first-line therapy, are ones that significantly diminish viral replication capacity [73, 74].

In contrast, the use of DTG as part of a second-line INSTI regimen may be more laden with problems, given the fact that mutations at positions 148, 140, and elsewhere within the viral genome, that are associated with resistance to RAL and EVG, may interfere with the ability of DTG to perform well. Moreover, the use of DTG to treat previously INSTI-experienced patients, with resistance to RAL and/or EVG, may lead to the selection of additional mutations that may further compromise therapy and cause cross-resistance [71]. Notably, in vitro studies suggest that the very rare individuals who may fail DTG treatment following emergence of the R263K mutation

Table 2 Representation of the potential evolution of HIV-1 following therapy of previously treatment-naive individuals with raltegravir, elvitegravir, or dolutegravir

\begin{tabular}{lllc}
\hline \multicolumn{2}{l}{ Treatment-naïve patients } & \\
\hline $\begin{array}{l}\text { Treatment } \\
\text { initiation }\end{array}$ & $\begin{array}{l}\text { Primary resistance } \\
\text { mutations }\end{array}$ & Compensatory mutations & $\begin{array}{c}\text { Clinical } \\
\text { outcome }\end{array}$ \\
\hline $\begin{array}{l}\text { Raltegravir/ } \\
\text { elvitegravir }\end{array}$ & E92Q, Y143R/C, N155H, & Y143C/T97A; Y143R/T97A; Y143G/L74M/T97A; & Virological \\
& & Y143C/L74 M/T97A/E138A & failure \\
& & N155H/L74M; E92Q/N155H & \\
& & E92Q/T66I; E92Q/S153A; E92Q/H51Y/L68V & \\
& & Q148H/K/R + E138A/K; Q148H/K/R + G140S/A; & \\
& & None & Viral \\
Dolutegravir & R263 K & & suppression \\
\hline
\end{tabular}

In rare cases, the emergence of resistance mutations in patients treated with raltegravir or elvitegravir can lead to virological failure (top). Virological failure with resistance mutations in treatment-naïve patients treated with dolutegravir has not been reported (bottom) 
may still be treatable with RAL but not with EVG [74]. As stated, the results of the VIKING studies showed that many patients who possessed mutations at positions 148 and 140 within integrase did not respond well to DTG [71]. In addition, such patients commonly developed additional mutations associated with the RAL/EVG resistance pathway. Thus, the potential sequential use of integrase inhibitors may be problematic, and the use of DTG in second-line regimens after resistance has developed against either RAL or EVG may ultimately represent a hazard to the long-term performance of DTG in the clinic. Of course, the choice of which INSTI to use in first-line regimens will be made by physicians in consultation with their patients based on considerations of drug efficacy, tolerability, safety, and ease of dosing. A summary of resistance pathways involving the use of various INSTIs to treat patients in first-line therapy can be found in Table 2 .

\section{CONCLUSION}

INSTIs are the most recent class of antiretroviral drugs. INSTIs can and should be used as part of first- and second-line regimens to treat individuals living with HIV. Due to its high genetic barrier for resistance, DTG may be used to treat patients who have previously failed treatment with RAL or EVG, but only under the circumstances described above. Overall, INSTIs are a major advance in the management of individuals living with HIV.

\section{ACKNOWLEDGMENTS}

This work was supported by an unrestricted educational grant from Gilead Sciences Inc. We thank Ms. Tamar Veres for excellent editorial assistance. Ms. Veres was employed at the McGill University AIDS Centre through funding provided by Gilead Sciences Inc.

Dr. Mark A Wainberg is the guarantor for this article, and takes responsibility for the integrity of the work as a whole.

Conflict of interest. Dr. Mesplède and Dr. Wainberg have no conflicts of interest to disclose.

Compliance with ethics guidelines. The analysis in this article is based on previously conducted studies, and does not involve any new studies of human or animal subjects performed by any of the authors.

Open Access. This article is distributed under the terms of the Creative Commons Attribution Noncommercial License which permits any noncommercial use, distribution, and reproduction in any medium, provided the original author(s) and the source are credited.

\section{REFERENCES}

1. Boyd SD. Management of HIV infection in treatment-naive patients: a review of the most current recommendations. Am J Health Syst Pharm. 2011;68:991-1001.

2. Whitney JB, Lim SY, Wainberg MA. Evolutionary mechanisms of retroviral persistence. AIDS Rev. 2011;13:234-9.

3. Wainberg MA, Zaharatos GJ, Brenner BG. Development of antiretroviral drug resistance. N Engl J Med. 2011;365:637-46.

4. Gupta RK, Jordan MR, Sultan BJ, Hill A, Davis DH, Gregson J, Sawyer AW, Hamers RL, Ndembi N, Pillay D, Bertagnolio S. Global trends in antiretroviral resistance in treatment-naive individuals with HIV after rollout of antiretroviral treatment in resource-limited settings: a global collaborative study and meta-regression analysis. Lancet. 2012;380(9849):1250-8. 
5. Blanco JL, Varghese V, Rhee SY, Gatell JM, Shafer RW. HIV-1 integrase inhibitor resistance and its clinical implications. J Infect Dis. 2011;203: 1204-14.

6. Mesplede T, Quashie PK, Wainberg MA. Resistance to HIV integrase inhibitors. Curr Opin HIV AIDS. 2012;7(5):401-98.

7. Wainberg MA, Mesplede T, Quashie PK. The development of novel HIV integrase inhibitors and the problem of drug resistance. Curr Opin Virol. 2012;2:656-62.

8. Quashie PK, Mesplede T, Wainberg MA. HIV drug resistance and the advent of integrase inhibitors. Curr Infect Dis Rep. 2012;15(1):85-100.

9. Orkin C, DeJesus E, Khanlou H, Stoehr A, Supparatpinyo K, Lathouwers E, Lefebvre E, Opsomer M, Van de Casteele T, Tomaka F. Final 192-week efficacy and safety of once-daily darunavir/ ritonavir compared with lopinavir/ritonavir in HIV-1-infected treatment-naive patients in the ARTEMIS trial. HIV Med. 2013;14:49-59.

10. Kempf DJ, King MS, Bernstein B, Cernohous $\mathrm{P}$, Bauer E, Moseley J, Gu K, Hsu A, Brun S, Sun E. Incidence of resistance in a double-blind study comparing lopinavir/ritonavir plus stavudine and lamivudine to nelfinavir plus stavudine and lamivudine. J Infect Dis. 2004;189:51-60.

11. Walmsley S, Bernstein B, King M, Arribas J, Beall G, Ruane P, Johnson M, Johnson D, Lalonde R, Japour A, et al. Lopinavir-ritonavir versus nelfinavir for the initial treatment of HIV infection. N Engl J Med. 2002;346:2039-46.

12. Llibre JM. First-line boosted protease inhibitorbased regimens in treatment-naive HIV-1-infected patients-making a good thing better. AIDS Rev. 2009;11:215-22.

13. Adams J, Patel N, Mankaryous N, Tadros M, Miller CD. Nonnucleoside reverse transcriptase inhibitor resistance and the role of the second-generation agents. Ann Pharmacother. 2010;44:157-65.

14. Puras Lutzke RA, Eppens NA, Weber PA, Houghten RA, Plasterk RH. Identification of a hexapeptide inhibitor of the human immunodeficiency virus integrase protein by using a combinatorial chemical library. Proc Natl Acad Sci USA. 1995;92:11456-60.

15. Ojwang JO, Buckheit RW, Pommier Y, Mazumder A, De Vreese K, Este JA, Reymen D, Pallansch LA, Lackman-Smith C, Wallace TL, et al. T30177, an oligonucleotide stabilized by an intramolecular guanosine octet, is a potent inhibitor of laboratory strains and clinical isolates of human immunodeficiency virus type 1. Antimicrob Agents Chemother. 1995;39:2426-35.

16. Hazuda DJ, Felock P, Witmer M, Wolfe A, Stillmock K, Grobler JA, Espeseth A, Gabryelski L, Schleif W, Blau C, Miller MD. Inhibitors of strand transfer that prevent integration and inhibit HIV-1 replication in cells. Science. 2000;287:646-50.

17. Delelis O, Carayon K, Saib A, Deprez E, Mouscadet JF. Integrase and integration: biochemical activities of HIV-1 integrase. Retrovirology. 2008;5:114.

18. Li X, Krishnan L, Cherepanov P, Engelman A. Structural biology of retroviral DNA integration. Virology. 2011;411:194-205.

19. Engelman A, Cherepanov P. The structural biology of HIV-1: mechanistic and therapeutic insights. Nat Rev Microbiol. 2012;10:279-90.

20. Waters LJ, Barber TJ. Dolutegravir for treatment of HIV: SPRING forwards? Lancet. 2013;381:705-6.

21. Wills T, Vega V. Elvitegravir: a once-daily inhibitor of HIV-1 integrase. Expert Opin Investig Drugs. 2012;21:395-401.

22. Katlama C, Murphy R. Dolutegravir for the treatment of HIV. Expert Opin Investig Drugs. 2012;21:523-30.

23. Wainberg MA, Quashie PK, Mesplede T. Dolutegravir HIV integrase inhibitor treatment of HIV infection. Drug Future. 2012;37:697-707.

24. Rockstroh JK, DeJesus E, Lennox JL, Yazdanpanah Y, Saag MS, Wan H, Rodgers AJ, Walker ML, Miller M, DiNubile MJ, et al. Durable efficacy and safety of raltegravir versus efavirenz when combined with tenofovir/emtricitabine in treatment-naive HIV-1infected patients: final 5-year results from STARTMRK. J Acquir Immune Defic Syndr. 2013;63:77-85.

25. Charpentier C, Bertine M, Visseaux B, Leleu J, Larrouy L, Peytavin G, Mourez T, Collin G, BrunVezinet F, Plantier JC, Descamps D. In-vitro phenotypic suscept 1 'non $b$ ' integrase inhibitors naive clinical isolates to dolutegravir and raltegravir. AIDS. 2013;27(18):2959-2961.

26. Briz V, Garrido C, Poveda E, Morello J, Barreiro P, de Mendoza C, Soriano V. Raltegravir and etravirine are active against HIV type 1 group O. AIDS Res Hum Retroviruses. 2009;25:225-7.

27. Messiaen $\mathrm{P}$, Wensing AM, Fun A, Nijhuis $M$, Brusselaers N, Vandekerckhove L. Clinical use of HIV integrase inhibitors: a systematic review and meta-analysis. PLoS ONE. 2013;8:e52562. 
28. Lennox JL, Dejesus E, Berger DS, Lazzarin A, Pollard RB, Ramalho Madruga JV, Zhao J, Wan H, Gilbert $\mathrm{CL}$, Teppler $\mathrm{H}$, et al. Raltegravir versus Efavirenz regimens in treatment-naive HIV-1-infected patients: 96-week efficacy, durability, subgroup, safety, and metabolic analyses. J Acquir Immune Defic Syndr. 2010;55:39-48.

29. Lennox JL, DeJesus E, Lazzarin A, Pollard RB, Madruga JV, Berger DS, Zhao J, Xu X, WilliamsDiaz A, Rodgers AJ, et al. Safety and efficacy of raltegravir-based versus efavirenz-based combination therapy in treatment-naive patients with HIV-1 infection: a multicentre, double-blind randomised controlled trial. Lancet. 2009;374: 796-806.

30. Markowitz M, Nguyen BY, Gotuzzo E, Mendo F, Ratanasuwan W, Kovacs C, Prada G, MoralesRamirez JO, Crumpacker CS, Isaacs RD, et al. Sustained antiretroviral effect of raltegravir after 96 weeks of combination therapy in treatmentnaive patients with HIV-1 infection. J Acquir Immune Defic Syndr. 2009;52:350-6.

31. Markowitz M, Nguyen BY, Gotuzzo E, Mendo F, Ratanasuwan W, Kovacs C, Prada G, MoralesRamirez JO, Crumpacker CS, Isaacs RD, et al. Rapid and durable antiretroviral effect of the HIV-1 integrase inhibitor raltegravir as part of combination therapy in treatment-naive patients with HIV-1 infection: results of a 48-week controlled study. J Acquir Immune Defic Syndr. 2007;46:125-33.

32. Eron JJ Jr, Rockstroh JK, Reynes J, AndradeVillanueva J, Ramalho-Madruga JV, Bekker LG, Young B, Katlama C, Gatell-Artigas JM, Arribas JR, et al. Raltegravir once daily or twice daily in previously untreated patients with HIV-1: a randomised, active-controlled, phase 3 noninferiority trial. Lancet Infect Dis. 2011;11:907-15.

33. Sax PE, DeJesus E, Mills A, Zolopa A, Cohen C, Wohl D, Gallant JE, Liu HC, Zhong L, Yale K, et al. Co-formulated elvitegravir, cobicistat, emtricitabine, and tenofovir versus co-formulated efavirenz, emtricitabine, and tenofovir for initial treatment of HIV-1 infection: a randomised, double-blind, phase 3 trial, analysis of results after 48 weeks. Lancet. 2012;379:2439-48.

34. Zolopa A, Sax PE, DeJesus E, Mills A, Cohen C, Wohl D, Gallant JE, Liu HC, Plummer A, White KL, et al. A randomized double-blind comparison of coformulated elvitegravir/cobicistat/emtricitabine/ tenofovir disoproxil fumarate versus efavirenz/ emtricitabine/tenofovir disoproxil fumarate for initial treatment of HIV-1 infection: analysis of week 96 results. J Acquir Immune Defic Syndr. 2013;63:96-100.
35. DeJesus E, Rockstroh JK, Henry K, Molina JM, Gathe J, Ramanathan S, Wei X, Yale K, Szwarcberg J, White $\mathrm{K}$, et al. Co-formulated elvitegravir, cobicistat, emtricitabine, and tenofovir disoproxil fumarate versus ritonavir-boosted atazanavir plus co-formulated emtricitabine and tenofovir disoproxil fumarate for initial treatment of HIV-1 infection: a randomised, double-blind, phase 3 , non-inferiority trial. Lancet. 2012;379:2429-38.

36. Rockstroh JK, DeJesus E, Henry K, Molina JM, Gathe J, Ramanathan S, Wei X, Plummer A, Abram M, Cheng $\mathrm{AK}$, et al. A randomized, double-blind comparison of coformulated elvitegravir/ cobicistat/emtricitabine/tenofovir DF vs ritonavirboosted atazanavir plus coformulated emtricitabine and tenofovir DF for initial treatment of HIV-1 infection: analysis of week 96 results. J Acquir Immune Defic Syndr. 2013;62:483-6.

37. Stellbrink HJ, Reynes J, Lazzarin A, Voronin E, Pulido F, Felizarta F, Almond S, St Clair M, Flack N, Min S. Dolutegravir in antiretroviral-naive adults with HIV-1: 96-week results from a randomized dose-ranging study. Aids. 2013;27:1771-8.

38. van Lunzen J, Maggiolo F, Arribas JR, Rakhmanova A, Yeni P, Young B, Rockstroh JK, Almond S, Song I, Brothers C, Min S. Once daily dolutegravir (S/GSK1349572) in combination therapy in antiretroviral-naive adults with HIV: planned interim 48 week results from SPRING-1, a doseranging, randomised, phase $2 \mathrm{~b}$ trial. Lancet Infect Dis. 2012;12:111-8.

39. Walmsley S, Antela A, Clumeck N, Duiculescu D, Eberhard A, Gutierrez F, Hocqueloux L, Maggiolo F, Sandkovsky U, Granier C, et al. Dolutegravir (DTG; S/GSK1349572) + abacavir/lamivudine once daily statistically superior to tenofovir/emtricitabine/ efavirenz: 48-week results-single (ING114467), 52nd ICAAC, San Francisco; 2013.

40. Paton N, Kityo C, Hoppe A, Hakim J, van Oosterhout J, Silka A, Mwaba P, Kambugu A, Easterbrook P, Boles J, et al. A pragmatic randomised controlled strategy trial of three second-line treatment options for use in public health rollout programme settings: the EuropeAfrica Research Network for Evaluation of Secondline Therapy (EARNEST) trial, 7th IAS Conference on HIV pathogenesis treatment and prevention, Kuala-Lumpur, Malaysia. 2013.

41. Boyd MA, Kumarasamy N, Moore CL, Nwizu C, Losso MH, Mohapi L, Martin A, Kerr S, Sohn AH, Teppler $\mathrm{H}$, et al. Ritonavir-boosted lopinavir plus nucleoside or nucleotide reverse transcriptase inhibitors versus ritonavir-boosted lopinavir plus raltegravir for treatment of HIV-1 infection in adults with virological failure of a standard firstline ART regimen (SECOND-LINE): a randomised, 
open-label, non-inferiority study. Lancet. 2013; 381:2091-9.

42. Nishijima T, Gatanaga $H$, Shimbo T, Komatsu $H$, Endo T, Horiba M, Koga M, Naito T, Itoda I, Tei M, et al. Switching tenofovir/emtricitabine plus lopinavir/r to raltegravir plus Darunavir/ $\mathrm{r}$ in patients with suppressed viral load did not result in improvement of renal function but could sustain viral suppression: a randomized multicenter trial. PLoS ONE. 2013;8:e73639.

43. Elion R, Molina JM, Ramon Arribas Lopez J, Cooper D, Maggiolo F, Wilkins E, Conway B, Liu YP, Margot $\mathrm{N}$, Rhee $\mathrm{M}$, et al. A randomized phase 3 study comparing once-daily elvitegravir with twice-daily raltegravir in treatment-experienced subjects with HIV-1 infection: 96-week results. J Acquir Immune Defic Syndr. 2013;63:494-7.

44. Molina JM, Lamarca A, Andrade-Villanueva J, Clotet B, Clumeck N, Liu YP, Zhong L, Margot N, Cheng AK, Chuck SL. Efficacy and safety of once daily elvitegravir versus twice daily raltegravir in treatment-experienced patients with HIV-1 receiving a ritonavir-boosted protease inhibitor: randomised, double-blind, phase 3 , non-inferiority study. Lancet Infect Dis. 2012;12:27-35.

45. Raffi F, Rachlis A, Stellbrink HJ, Hardy WD, Torti C, Orkin C, Bloch M, Podzamczer D, Pokrovsky V, Pulido F, et al. Once-daily dolutegravir versus raltegravir in antiretroviral-naive adults with HIV1 infection: 48 week results from the randomised, double-blind, non-inferiority SPRING-2 study. Lancet. 2013;381:735-43.

46. Cahn P, Pozniak AL, Mingrone H, Shuldyakov A, Brites C, Andrade-Villanueva JF, Richmond G, Buendia CB, Fourie J, Ramgopal $M$, et al. Dolutegravir versus raltegravir in antiretroviralexperienced, integrase-inhibitor-naive adults with HIV: week 48 results from the randomised, doubleblind, non-inferiority SAILING study. Lancet. 2013;382:700-8.

47. Feinberg J, Clotet B, Khuong M, Antinori A, van Lunzen J, Dumitru I, Pokrosky V, Fehr J, Ortiz R, Saag MS, et al. Once-daily dolutegravir (DTG) is superior to darunavir/ritonavir (DRV/r) in antiretroviral naive adults: 48 week results from FLAMINGO (ING114915), Abstract H-1464a, 53rd ICAAC Conference, Denver. 2013.

48. Reynes J, Lawal A, Pulido F, Soto-Malave R, Gathe J, Tian M, Fredrick LM, Podsadecki TJ, Nilius AM. Examination of noninferiority, safety, and tolerability of lopinavir/ritonavir and raltegravir compared with lopinavir/ritonavir and tenofovir/ emtricitabine in antiretroviral-naive subjects: the progress study, 48-week results. HIV Clin Trials. 2011;12:255-67.
49. Reynes J, Trinh R, Pulido F, Soto-Malave R, Gathe J, Qaqish R, Tian M, Fredrick L, Podsadecki T, Norton M, Nilius A. Lopinavir/ritonavir combined with raltegravir or tenofovir/emtricitabine in antiretroviral-naive subjects: 96 -week results of the PROGRESS study. AIDS Res Hum Retroviruses. 2013;29:256-65.

50. Taiwo B, Zheng L, Gallien S, Matining RM, Kuritzkes DR, Wilson CC, Berzins BI, Acosta EP, Bastow B, Kim PS, Eron JJ Jr. Efficacy of a nucleoside-sparing regimen of darunavir/ritonavir plus raltegravir in treatment-naive HIV-1-infected patients (ACTG A5262). Aids. 2011;25:2113-22.

51. Kozal MJ, Lupo S, DeJesus E, Molina JM, McDonald C, Raffi F, Benetucci J, Mancini M, Yang R, Wirtz V, et al. A nucleoside- and ritonavir-sparing regimen containing atazanavir plus raltegravir in antiretroviral treatment-naive HIV-infected patients: SPARTAN study results. HIV Clin Trials. 2012;13:119-30.

52. Song I, Borland J, Chen S, Lou Y, Peppercorn A, Wajima T, Min S, Piscitelli SC. Effect of atazanavir and atazanavir/ritonavir on the pharmacokinetics of the next-generation HIV integrase inhibitor, S/GSK1349572. Br J Clin Pharmacol. 2011;72: 103-8.

53. Song I, Borland J, Min S, Lou Y, Chen S, Patel P, Wajima T, Piscitelli SC. Effects of etravirine alone and with ritonavir-boosted protease inhibitors on the pharmacokinetics of dolutegravir. Antimicrob Agents Chemother. 2011;55:3517-21.

54. Song I, Min SS, Borland J, Lou Y, Chen S, Patel P, Ishibashi T, Piscitelli SC. The effect of lopinavir/ ritonavir and darunavir/ritonavir on the HIV integrase inhibitor S/GSK1349572 in healthy participants. J Clin Pharmacol. 2011;51:237-42.

55. Schafer JJ, Squires KE. Integrase inhibitors: a novel class of antiretroviral agents. Ann Pharmacother. 2010;44:145-56.

56. Cooper DA, Steigbigel RT, Gatell JM, Rockstroh JK, Katlama C, Yeni P, Lazzarin A, Clotet B, Kumar PN, Eron JE, et al. Subgroup and resistance analyses of raltegravir for resistant HIV-1 infection. N Engl J Med. 2008;359:355-65.

57. Steigbigel RT, Cooper DA, Kumar PN, Eron JE, Schechter M, Markowitz M, Loutfy MR, Lennox JL, Gatell JM, Rockstroh JK, et al. Raltegravir with optimized background therapy for resistant HIV-1 infection. N Engl J Med. 2008;359:339-54.

58. Eron JJ, Cooper DA, Steigbigel RT, Clotet B, Gatell JM, Kumar PN, Rockstroh JK, Schechter M, Markowitz M, Yeni P, et al. Efficacy and safety of raltegravir for treatment of HIV for 5 years in the 
BENCHMRK studies: final results of two randomised, placebo-controlled trials. Lancet Infect Dis. 2013;13:587-96.

59. Steigbigel RT, Cooper DA, Teppler H, Eron JJ, Gatell JM, Kumar PN, Rockstroh JK, Schechter M, Katlama C, Markowitz M, et al. Long-term efficacy and safety of Raltegravir combined with optimized background therapy in treatment-experienced patients with drug-resistant HIV infection: week 96 results of the BENCHMRK 1 and 2 Phase III trials. Clin Infect Dis. 2010;50:605-12.

60. Grinsztejn B, Nguyen BY, Katlama C, Gatell JM, Lazzarin A, Vittecoq D, Gonzalez CJ, Chen J, Harvey CM, Isaacs RD. Safety and efficacy of the HIV-1 integrase inhibitor raltegravir (MK-0518) in treatment-experienced patients with multidrugresistant virus: a phase II randomised controlled trial. Lancet. 2007;369:1261-9.

61. Gatell JM, Katlama C, Grinsztejn B, Eron JJ, Lazzarin A, Vittecoq D, Gonzalez CJ, Danovich RM, Wan H, Zhao J, et al. Long-term efficacy and safety of the HIV integrase inhibitor raltegravir in patients with limited treatment options in a phase II study. J Acquir Immune Defic Syndr. 2010;53:456-63.

62. Fagard C, Colin C, Charpentier C, Rami A, Jacomet C, Yeni P, Vittecoq D, Katlama C, Molina JM, Descamps D, et al. Long-term efficacy and safety of raltegravir, etravirine, and darunavir/ritonavir in treatment-experienced patients: week 96 results from the ANRS 139 TRIO trial. J Acquir Immune Defic Syndr. 2012;59:489-93.

63. Podzamczer D, Martinez E, Domingo P, Ferrer E, Viciana P, Curto J, Perez-Elias MJ, Ocampo A, Santos I, Knobel $\mathrm{H}$, et al. Switching to raltegravir in virologically suppressed in HIV-1-infected patients: a retrospective, multicenter, descriptive study. Curr HIV Res. 2012;10:673-8.

64. Eron JJ, Young B, Cooper DA, Youle M, Dejesus E, Andrade-Villanueva J, Workman C, Zajdenverg R, Fatkenheuer G, Berger DS, et al. Switch to a raltegravir-based regimen versus continuation of a lopinavir-ritonavir-based regimen in stable HIVinfected patients with suppressed viraemia (SWITCHMRK 1 and 2): two multicentre, doubleblind, randomised controlled trials. Lancet. 2010;375:396-407.

65. Martin A, Moore C, Mallon PW, Hoy J, Emery S, Belloso W, Phanuphak P, Ferret S, Cooper DA, Boyd MA. Bone mineral density in HIV participants randomized to raltegravir and lopinavir/ritonavir compared with standard Second Line therapy. AIDS. 2013;27(15):2403-2411.

66. Buzon MJ, Massanella M, Llibre JM, Esteve A, Dahl V, Puertas MC, Gatell JM, Domingo P, Paredes R,
Sharkey M, et al. HIV-1 replication and immune dynamics are affected by raltegravir intensification of HAART-suppressed subjects. Nat Med. 2010;16:460-5.

67. Gandhi RT, Coombs RW, Chan ES, Bosch RJ, Zheng L, Margolis DM, Read S, Kallungal B, Chang M, Goecker EA, et al. No effect of raltegravir intensification on viral replication markers in the blood of HIV-1-infected patients receiving antiretroviral therapy. J Acquir Immune Defic Syndr. 2012;59:229-35.

68. Charpentier C, Fagard C, Colin C, Katlama C, Molina JM, Jacomet C, Visseaux B, Taburet AM, Brun-Vezinet F, Chene $G$, et al. Role of baseline HIV-1 DNA level in highly-experienced patients receiving raltegravir, etravirine and darunavir/ ritonavir regimen (ANRS139 TRIO trial). PLOS ONE. 2013;8:e53621.

69. Chege D, Kovacs C, la Porte C, Ostrowski M, Raboud J, Su D, Kandel G, Brunetta J, Kim CJ, Sheth PM, et al. Effect of raltegravir intensification on HIV proviral DNA in the blood and gut mucosa of men on long-term therapy: a randomized controlled trial. Aids. 2012;26:167-74.

70. Guidelines for the use of antiretroviral agents in HIV1-infected adults and adolescents. Available at: http://aidsinfo.nih.gov/guidelines. Accessed 17 Oct 2013.

71. Eron JJ, Clotet B, Durant J, Katlama C, Kumar P, Lazzarin A, Poizot-Martin I, Richmond G, Soriano $\mathrm{V}$, Ait-Khaled $\mathrm{M}$, et al. Safety and efficacy of dolutegravir in treatment-experienced subjects with raltegravir-resistant HIV type 1 infection: 24-week results of the VIKING Study. J Infect Dis. 2013;207:740-8.

72. Underwood M, Dudas K, Horton J, Wang R, Deanda F, Griffith S, Dorey D, Hightower KE. Analysis and characterization of treatment-emergent resistance in ART-experienced, integrase inhibitor-naive subjects with dolutegravir (DTG) versus raltegravir (RAL) in SAILING (ING111762). International Workshop on HIV and Hepatitis Drug Resistance and Curative Strategies, Toronto. 2013.

73. Quashie PK, Mesplede T, Han YS, Oliveira M, Singhroy DN, Fujiwara T, Underwood MR, Wainberg MA. Characterization of the R263K mutation in HIV-1 integrase that confers low-level resistance to the second-generation integrase strand transfer inhibitor dolutegravir. J Virol. 2012;86:2696-705.

74. Mesplede T, Quashie PK, Osman N, Han Y, Singhroy DN, Lie Y, Petropoulos CJ, Huang W, Wainberg MA. Viral fitness cost prevents HIV-1 from evading dolutegravir drug pressure. Retrovirology. 2013;10:22. 